\title{
PENINGKATAN DAYA SAING PRODUK KONVEKSI USAHA KECIL BERBASIS IPTEK DI DESA TRI TUNGGAL KECAMATAN BABAT LAMONGAN
}

\author{
Arasy Alimudin ${ }^{1}$, Agus Dwi Sasono ${ }^{2}$, \\ Manajemen Fakultas Ekonomi dan Bisnis \\ Universitas Narotama Surabaya \\ arasybest@gmail.com
}

\begin{abstract}
ABTRACT
Research purposes are improving competitiveness of garment products at Tri Tunggal village, Babat -Lamongan districts. Entrepreneurs convection problems at Tri Tunggal village lies in production factors is still done by manual processes, no financial report and products marketing rely on sales promotions so the impact on low production levels and less able to compete with competitors. The method used is qualitative method. Research results is an partner's using production technology ability and marketing are increased, so have an influence on improving the competitiveness of garment products at UD. Putra Tunggal. It can be seen from product designs and customers number, and profit margins are increased.
\end{abstract}

Keyword: Product Design, garment produc, competitiveness, marketing.

\section{I.PENDAHULUAN}

Desa Tri Tunggal Kecamatan Babat Lamongan merupakan salah satu desa terletak $74 \mathrm{KM}$ sebelah barat kota Surabaya, Desa Tri Tunggal merupakan sentra industri konveksi yang memproduksi kaos, jaket, kostum olah raga dan seragam sekolah, jumlah industri konveksi yang ada di desa tersebut sebanyak 143 pengusaha konveksi dan memperkerjakan 1834 tenaga kerja. Akses pemasaran industri konveksi di Desa Tri Tunggal sudah mencapai seluruh Indonesia diantaranya Kalimantan, Maluku, Sula wesi, Sumatera sampai dengan Papua. Omzet penjualan rata-rata per UKM menjacapai 60 juta sampai dengan 100 Juta rupiah per UKM perbulan, omzet penjualan sangat meningkat tajam pada saat menjelang pemilu maupun pilkada serta anak masuk sekolah.

Permasalahan yang dialami oleh usaha konveksi di Desa Tri Tunggal adalah masih bannyak UKM konveksi dalam proses produksinya masih menggunkan proses manual serta belum digunakan teknologi komputer dalam membuat desain produk sehingga produk yang dihasilkan memakan waktu yang lama dan kurang efisien serta kurang dapat bersaing dengan kompetitor. Teknologi desain sablon dengan komputer sudah sangat canggih baik corak warna maupun motif gambar sangat variatif bila dibandingkan dengan sablon manual, yang menjadi kendala saat ini adalah skill para pegawai yang ada belum mampu mengoprasikan aplikasi tersebut. Hal inilah menjadikan produk konveksi yang dihasilkan kurang bisa bersaing dibandingkan produk yang sejenis.

Selain itu metode pemasaran yang dilakukan oleh pengusaha konveksi di Desa Tri Tunggal selama ini hanya mengandalkan para sales dan disebarkan ke pelosok tanah air, metode pemasaran dengan menggunakan salas promotion membutuhkan biaya yang cukup besar dan tidak efisien karena memerlukan biaya yang cukup besar sampai ditangan konsumen.

Referensi[1] menunjukkan bahwa Pemanfaatan teknologi informasi mempunyai dampak positif terhadap strategi manajemen. Penggunaan teknologi informasi dapat menjadikan sebuah kekuatan dalam menentukan strategi serta dapat digunakan sebagai alat bagi organisasi bisnis dalam memberikan keuntungan pada aspek promosi dan kekuatan daya saing[2].Referensi[3] menunjukkan bahwa teknologi informasi dapat memberikan keuntungan bagi dunia bisnis dalam mengurangi biaya serta meningkatkan kemampuan dunia usaha dalam melakukan koordinasi dengan pihak luar. Referensi[5] menunjukkan bahwa penggunaan komputer dapat meningkatkan kemampuan usaha kecil menengah dalam memberikan pelayanan semakin baik dan meningkatkan daya saing produk. Referensi[6] menunjukkan bahwa Peran komputer dalam meningkatkan daya saing usaha kecil menengah perlu memanfaatkan teknologi Informasi untuk meningkatkan daya saingnya, mengingat di era globalisasi ini arena persaingan semakin kompetitif. Referensi[7] menunjukkan bahwa pentingmya usaha kecil dan menengah untuk melakukan inovatif dan menghasilkan produk dengan kualitas tinggi untuk berhasil dalam kompetisi global. Untuk dapat bersaing usaha kecil dituntut untuk menghasilkan produk yang memiliki ciri khas serta keuanikan dalam produk tersebut sehingga dapat diterima oleh pasar dan dapat bersaing dengan kompetitor.

Referensi[8] menunjukkan bahwa alasan mendasar mengapa perusahaan di Jepang menjadi sukses karena keterampilan dan pengalaman mereka meningkatkan 
pengetahuan organisasi. Penciptaan knowledge dicapai melalui pengenalan hubungan yang sinergik antara knowledge tacit dan explicit .

Referensi[9] menunjukkan bahwa terdapat empat faktor dalam meningkatkan kemampuan usaha kecil menengah untuk dapat bersaing yaitu kemampuan penguasaan ilmu pengetahuan. Keterampilan serta memiliki etos kerja. Memiliki pengetahuan teknis antara penguasaan penggunaan teknologi dan peningkatan nilai tambah serta mampu menciptakan suatu produktivitas yang tinggi.

e-commerce mempunyai peranan penting terhadap daya saing produk, karena didalam $e$ commerce perusahaan dapat melakukan promosi penjualan serta dapat berinteraksi secara langsung dengan pelanggan yang berdampak pada meningkatkan volume penjualan serta mampu mempromosikan produk-produk industri cukup tinggi. seperti dalam [10]

\section{II.METO DE PENELITIAN}

Metode penelitian yang digunakan adalah metode penelitian partisipatif yakni proses belajar bersama antara peneliti dengan kelompok masyarakat untuk meningkatkan pemahaman secara kritis terhadap persoalan-persoalan yang dihadapinya.Riset partisipatif terdiri dari tiga proses yang saling berhubungan, yaitu :

A. Penelitian bersama tentang persoalan-persoalan yang dihadapi dengan partisipasi aktif seluruh peserta dalam seluruh proses.

B. Analisis bersama, dimana para peserta mengembangkan suatu pengertian yang lebih baik, peserta tidak hanya mengenal masalahmasalah yang dihadapi,tetapi juga faktorfaktor penyebabnya. Focus pemberdayaan dalam penelitian ini adalah UD. Putra Tunggal dan UD Fauzul Jaya mampu menyelesaikan permasalahan yang berkenaan dengan desain produk dan dapat memasarkan produknya secara luas kepada masyarakat yang selama ini belum dapat dilakukan dengan baik.

C. Aksi bersama, dimana para peserta mengarahkan cara pemecahan masalah tersebut,baik dalam jangka pendek maupun jangka panjang.Aksi bersama yang dilakukan adalah melalui pelatihan dan pendampingan;1.Disain Produk dengan menggunakan computer;2.Pemasaran secara elektronik berbasis web;3.Pengelolaan keuangan.Diharapkan dengan tiga solusi tersebut dapat meningkatkan produktivitas serta penjualan produk konveksi pada UD Fauzul Jaya dan UD. Putra Tunggal di Desa Tri Tungal Kecamatan Babat Lamongan sehingga dapat meningkatkan produktivitas dan mampu bersaing dengan kompetitor, serta dapat meningkatkan perekonomian dan kesejahteraan masyarakat di sekitarnya.

Dalam penelitian partisipatif ini posisi peneliti yang dianggap sebagai orang luar bertindak sebagai fasilitator.Informasi yang diperoleh, kemudian dianalisis bersama dan diaplikasikan langsung oleh masyarakat.hasil yang diharapkan dari kegiatan penelitian partisipatif adalah perubahan perilaku sehingga dalam jangka panjang terbentuk kelembagaan dan tindakan masyarakat yang berkelanjut an.Seperti dalam [11].

D. Metode Pengumpulan Data dilakukan melalui pengumpulan Data sekunder dikumpulkan dengan metode dokumentasi.Sedangkan data primer dari narasumber dikumpulkan melalui wawancara mendalam yang dipandu dengan pedoman wa wancara yang telah dipersiapkan.

E. Teknik analisa data yang digunakan dalam penelitian ini Pertama adalah teknik analisis deskriptif digunakan untuk mengkaji karakteristik dari permasalahan yang dihadapi oleh UD Fauzul Jaya dan UD. Putra Tunggal di Desa Tri Tungal Kecamatan Babat Lamongan.Dan merumuskan keunggulan dan daya saing dari UD Fauzul Jaya dan UD. Putra Tunggal di Desa Tri Tungal Kecamatan Babat Lamongan.Teknik analisa deskriptif juga digunakan untuk menguraikan kaji tindak metode dan pelaksanaan pelatihan dan pendampingan;1.Disain Produk dengan menggunakan computer;2.Pemasaran secara elektronik berbasis web;3.Pengelolaan keuangan.Diharapkan dengan tiga solusi tersebut dapat meningkatkan produktivitas serta penjualan produk konveksi pada UD Fauzul Jaya dan UD. Putra Tunggal di Desa Tri Tungal Kecamatan Babat Lamongan.Jangka waktu penelitian ini adalah 6 bulan mulai bulan mei sampai dengan bulan oktober 2015 .

\section{III.PEMBAHASAN}

UD Fauzul Jaya dan UD. Putra Tunggal Konveksi merupakan Usaha Kecil Menengah yang beralamat di Desa Tri Tunggal Kecamat an Babat Lamongan. Usaha ini bergerak dalam bidang konveksi yang memproduksi berbagai jenis kaos, kostum olah raga, jaket, taplak meja, baju tidur dan seragam sekolah. Usaha ini didirikan sejak tahun 1992 dan sudah mempunyai 19 orang tenaga kerja. Permasalahan yang terjadi di UD Fauzul Jaya dan UD. Putra Tunggal adalah produk yang dihasilkan kurang dapat bersaing dengan kompetitor yang disebabkan oleh proses produksi masih menggunakan cara manual serta belum digunakan teknologi moderen dalam proses produksi dan pemasaran sehingga produktivitasnya rendah serta kurang efisien. Selain itu metode pamasaran yang dilakukan oleh pengusaha konveksi di Desa Tri Tunggal selama ini hanya mengandalkan para sales dan disebarkan ke pelosok tanah air, metode pemasaran dengan menggunakan sales promotion 
membutuhkan biaya yang cukup besar dan tidak efisien karena memerlukan biaya yang cukup besar sampai ditangan konsumen

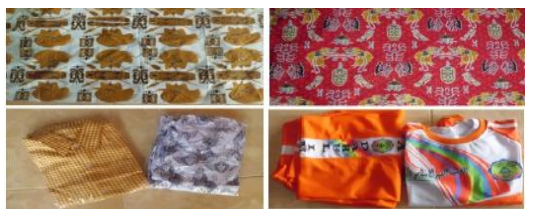

Gambar 2 Produk yang dihasilkan UD.Putra Tunggal

Upaya yang dilakukan untuk meningkatkan daya saing produk dapat dilakukan dengan dua pendekatan yaitu :

1.Peningkatan kemampuan usaha kecil menengah dalam meningkatkan kualitas produk Berbasis Iptek. Upaya peningkatan yang dilakukan dalam meningkatkan kualitas produk pada UD Fauzul Jaya dan UD. Putra Tunggal Konveksi adalah dengan cara melakukan pendampingan dan pelat ihan kepada mitra dalam membuat desain produk berbasis komputer. Produk konveksi merupakan produk fashion yang mengutamakan unsur modes dan seni untuk itu diperlukan keunikan serta model yang menarik hingga dapat memenuhi keinginan pelanggan serta pelanggan puas atas produk yang dihasilkan. Untuk memenuhi unsur tersebut UD Fauzul Jaya dan UD. Putra Tunggal konveksi harus mampu membuat model yang unik dan mempunyai unsur seni yang tinggi, untuk itu dibutuhkan teknologi komputer dalam membuat desain produk konveksi sehingga lebih menarik, lebih tajam serta kratif untuk dapat bersaing dengan kompetitor, salah satu program komputer yang dapat dipakai untuk membuat desain produk adalah program corel draw, program ini mempunyai keunggulan dalam dalam membuat desain atau gambar. Corel Draw merupakan salah alat untuk mendesain grafis dengan mengunakan komputer, keungulan dari corel draw ini berbasis vector, sehingga menghasilkan desain gambar yang lebih detail sesuai dengan keinginan desainer, selain itu Corel Draw penggunaannya cukup mudah, Corel Draw memiliki keuanggulan pewarnaan yang baik juga mempunyai fungsi sebagai alat bantu untuk merancang produk bagi perencana atau perancang dalam waktu yang relatif singkat dengan tingkat keakurasian yang tinggi. Corel Draw mempunyai keunggulan dalam membentuk gambar atau model. Dalam bentuk gambar berupa gambar 2 dimensi (2D) dan Gambar 3 dimensi (3D) sebagai visualisasi. Serta dapat membentuk model dapat berupa animasi dari obyek rancangan yang menvisualisasikan obyek sesungguhnya yang akan dihasilkan.

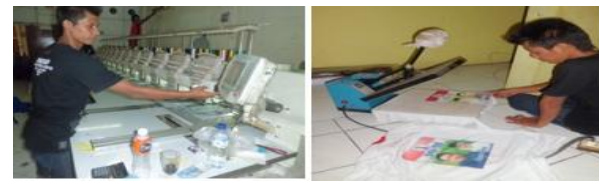

Gambar 03. Teknologi Yang Diajarkan Kepada Mitra UKM Konveksi
Kunci sukses sebuah produk haruslah mempunyai keunikan dan memiliki kualitas yang unggul, Kualitas produk sangatlah penting bagi perusahaan mengingat kualitas merupakan kemampuan yang dimiliki sebuah produk untuk memenuhi kebutuhan atau keinginan konsumen. Jika kualitas produk semakin meningkat, akan berdampak menurunnya keluhan konsumen. Salah satu yang menjadi ciri khas dan keunikan disain produk UD. Putra Tunggal konveksi adalah mampu memberikan ciri khas jahitan yang menunjukan spesifikasi pelanggan untuk kantor khususnya instansi pemerintah dan UD Fauzul Jaya mampu memberikan ciri khas jahitan yang menunjukan spesifikasi pelanggan untuk sekolah.

Tabel Hasil Analisis Pengamatan Kemampuan membuat disain produk menggunakan computer

\begin{tabular}{|c|c|c|c|c|}
\hline \multicolumn{2}{|c|}{ Kegiatan Pengamatan } & $\begin{array}{c}\text { Base } \\
\text { line }\end{array}$ & $\begin{array}{c}\text { 3 bulan } \\
\text { pertama }\end{array}$ & $\begin{array}{c}\text { 3 bulan } \\
\text { kedua }\end{array}$ \\
\hline 1 & $\begin{array}{c}\text { Kemampuan } \\
\text { mendesain produk }\end{array}$ & $\begin{array}{c}\text { Rendah } \\
(20 \%)\end{array}$ & $\begin{array}{c}70 \% \\
\text { ma mpu }\end{array}$ & $\begin{array}{c}90 \% \\
\text { ma mpu }\end{array}$ \\
\hline 2 & $\begin{array}{c}\text { Kemampuan } \\
\text { menggunakan } \\
\text { teknologi }\end{array}$ & $\begin{array}{c}\text { Rendah } \\
(20 \%)\end{array}$ & $\begin{array}{c}60 \% \\
\text { ma mpu }\end{array}$ & $\begin{array}{c}70 \% \\
\text { ma mpu }\end{array}$ \\
\hline 3 & $\begin{array}{c}\text { Kemampuan } \\
\text { mengembangkan } \\
\text { Model }\end{array}$ & $\begin{array}{c}\text { Rendah } \\
(20 \%)\end{array}$ & $\begin{array}{c}40 \% \\
\text { ma mpu }\end{array}$ & $\begin{array}{c}80 \% \\
\text { ma mpu }\end{array}$ \\
\hline 4 & $\begin{array}{c}\text { Waktu Penyelesaian } \\
\text { Disain Produk }\end{array}$ & $\begin{array}{c}\text { Rendah } \\
(20 \%)\end{array}$ & $\begin{array}{c}40 \% \\
\text { mampu }\end{array}$ & $\begin{array}{c}80 \% \\
\text { mampu }\end{array}$ \\
\hline
\end{tabular}

Sumber: data pengamatan diolah 2015

Dari hasil pelatihan dan pendampingan yang dilakukan kepada pada UD Fauzul Jaya dan UD. Putra Tunggal dapat dihasilkan bahawa kemampuan mitra dalam membuat disain produk mengalami peningkatan dari 18 model yang dihasilkan selama ini mengalami peningkatan sebesar 24 model, hal ini dikarnakan kemampuan mitra dalam menggunakan komputer dalam membuat desain produk mengalami peningkatan hal ini dapat dilihat dari corak warna serta model yang dihasilkan lebih variatif dan inovatif bila dibandingkan dengan sebelumnya. Waktu penyelesaian produk sebelum digunakan teknologi membutuhkan waktu 15 menit setiap produk lebih cepat bila dibandingkan sebeumnya yaitu 25 Menit. Dari hasil pendampingan ini juga dapat diketahui kemampuan mitra UD Fauzul Jaya dan UD. Putra Tunggal dalam menggunakan teknologi produksi mengalami peningkatan dari kurang mampu menggunakan teknologi industri menjadi mampu.

2.Peningkatan Kemampuan Usaha Kecil Menengah Dalam Memperluas Pangsa Pasar. Upaya peningkatan kemampuan pemasaran produk UD Fauzul Jaya dan UD. Putra Tunggal konveksi adalah dengan melakukan pendampingan dan pelatihan pembuatan ecomerce, hal ini dilakukan karena pangsa pasar yang dimiliki oleh UD Fauzul Jaya dan UD. Putra Tunggal adalah di luar jawa,e-commerce sangatlah penting dalam mengenalkan produk yang dihasilkan serta untuk memotong pantai rantai penjualan yang selama ini dilakukan yaitu penjualan melalui sales promotion. peran web. sangat vital dalam melakukan promosi kepada masyarakat sehingga produk tersebut dapat 
dikenal oleh pasar. Selain segi ekonomis, manfaat lain yang dapat Anda peroleh dari pemasaran melalui internet produk Fleksibilitas merupakan manfaat yang signifikan dimana produk dapat dipasarkan secara luas dengan biaya yang sangat murah dan dapat diakses ke seluruh penjuru tanah air. Keungulan yang lain dari ecommerce adalah bisa diakses 24 jam non stop. Selain itu dengan digunakannya pemasaran produk konveksi dengan berbasis web dapat memotong mata rantai pemasaran yang dilakukan selama ini yaitu pemasaran yang hanya mengandalkan para sales.

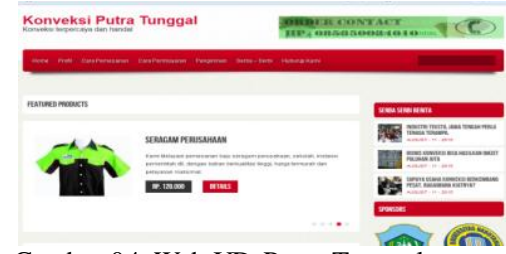

Gambar 04. Web UD.Putra Tunggal

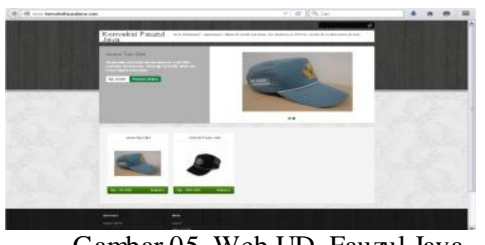

Kemampuan mitra dalam memasarkan produk juga mengalami peningkatan sejak digunakan e-commerce jumlah pelanggan mengalami peningkatan dari 32 pelanggan meningkat menjadi 44 pelanggan selain itu harga jual produk juga mengalami peningkatan sebesar 7 persen hal ini dipengaruhi oleh banyaknya pembelian langsung dari produsen langsung kepada konsumen.

Hasil penelitian ini mendukung teori yang dikemukakan dalam[10] yang menyatakan e-commerce mempunyai peranan penting terhadap daya saing produk, karena didalam e-commerce perusahaan dapat melakukan promosi penjualan serta dapat berinteraksi secara langsung dengan pelanggan yang berdampak pada meningkatkan volume penjualan. Selain itu penggunaan e-commerce dapat mendongkrak peningkatan volume penjualan dan mempromosikan produk-produk industri cukup tinggi seperti dalam[3]. Hasil penelitian ini juga mendukung teori dalam[7] menyatakan pentingmya usaha kecil dan menengah untuk melakukan inovatif dan menghasilkan produk dengan kualitas tinggi untuk berhasil dalam kompetisi global.Pengusaha Konveksi Desa Tri Tunggal menimplementasikan e-commerce melalui website sebagai media untuk menunjukan kepada pasartentang keunggulan produknya,dan ini menjadi posisioning mereka untuk dapat meningkatkan pangsa pasar mereka baik dari sisi peningkatan volume penjualan maupun peningkatan segmen pasar mereka.Mereka juga mampu bersaing dari harga karena mampu memotong mata rantai distribusi hingga sampai kepada pengguna langsung, dan ini meningkatkan profit mereka.
Tabel Hasil Analisis Pengamatan Kemampuan menggunakan web sebagai alat bantu pemasaran

\begin{tabular}{|c|c|c|c|c|}
\hline \multicolumn{2}{|c|}{ Kegiatan Pengamatan } & $\begin{array}{c}\text { Base } \\
\text { line }\end{array}$ & $\begin{array}{c}\text { 3 bulan } \\
\text { pertama }\end{array}$ & $\begin{array}{c}\text { 3 bulan } \\
\text { kedua }\end{array}$ \\
\hline 1 & $\begin{array}{c}\text { Kemampuan } \\
\text { Memasarkan Produk }\end{array}$ & $\begin{array}{c}\text { Rendah } \\
(20 \%)\end{array}$ & $\begin{array}{c}40 \% \\
\text { ma mpu }\end{array}$ & $\begin{array}{c}80 \% \\
\text { ma mpu }\end{array}$ \\
\hline 2 & $\begin{array}{c}\text { Peningkatan Jumlah } \\
\text { pelanggan }\end{array}$ & $\begin{array}{c}32 \\
\text { pelangga } \\
\mathrm{n}\end{array}$ & $\begin{array}{c}\text { Meningkat } \\
20 \%\end{array}$ & $\begin{array}{c}\text { Meningka } \\
\mathrm{t} 43 \%\end{array}$ \\
\hline 3 & $\begin{array}{c}\text { Kemampuan } \\
\text { penggunaan web }\end{array}$ & 0 & $25 \%$ & $45 \%$ \\
\hline
\end{tabular}

Sumber: data pengamatan diolah 2015

3.Pada kegiatan pelatihan dan pendampingan peningkatan kemampuan mitra dalam mengelola keuangan, kegiatan yang dilakukan meliputi mencatat transaksi akuntansi dan pembuatan laporan keuangan. Diharapkan mitra dapat mengelola keuangan dengan baik dan benar. Upaya yang dilakukan oleh Tim pelaksana PPM IbM dalam meningkatkan kemampuan dalam mengelola keuangan adalah dengan melakukan pelatihan serta pendampingan kepada pemilik perusahaan dalam melakukan pencatatan transaksi akuntansi sehingga pemilik perusahaan mampu melakukan pencatatan dan pengelolaan keuangan secara baik dan benar. Pembukuan bagi Usaha kecil menengah merupakan indikator kunci kinerja usaha kecil menengah , karena dengan pembukuan yang baik maka informasi yang disediakan oleh catatan akuntansi dapat digunakan oleh manajer dalam mengambil suatu keputusan bisnis, sehingga dapat meningkatkan pengelolaan keuangan perusahaan. Dengan pengelolaan pembukuan yang baik dan benar para pengusaha konveksi dapat melakukan identifikasi dan memprediksi setiap kesalahan yang timbul dan dapat melakukan koreksi tepat waktu sehingga resiko kebangkrutan dapat dihindari, bahkan karena mampu mendeteksi sejak dini perbandingan antara biaya dan harga,serta kedisiplinan didalam penggunan keuangan,dapat meningkatkan keuntungan pengusaha konveksi dari $15 \%$ menjadi $25 \%$.Hasil pengamatan juga menunjukan bahwa manfaat penyusunan laporan keuangan bagi pengusaha kecil konveksi desa tri tunggal adalah sebagai alat evaluasi untuk menilai perkembangan dan kesehatan usaha dan mereka mampu mengetahui kekayaan yang dihasilkan dari usaha mereka. Untuk mengetahui besaran tingkat keuntungan yang mereka dapatkan.

Tabel Hasil Analisis Pengamatan Kemampuan membuat Transaksi Keuangan

\begin{tabular}{|c|c|c|c|c|}
\hline \multicolumn{2}{|r|}{ Kegiatan Pengamatan } & \multirow{2}{*}{$\begin{array}{c}\begin{array}{c}\text { Base } \\
\text { line }\end{array} \\
\text { Rendah } \\
(20 \%)\end{array}$} & \multirow{2}{*}{$\begin{array}{c}\begin{array}{c}\text { 3 bulan } \\
\text { pertama }\end{array} \\
40 \% \\
\text { ma mpu }\end{array}$} & \multirow{2}{*}{$\begin{array}{c}\begin{array}{c}3 \text { bulan } \\
\text { kedua }\end{array} \\
80 \% \\
\text { ma mpu }\end{array}$} \\
\hline 1 & $\begin{array}{c}\text { Kemampuan Melakukan } \\
\text { Catatan pembukuan }\end{array}$ & & & \\
\hline 2 & $\begin{array}{c}\text { Kemampuan membuat } \\
\text { laporan keungan }\end{array}$ & $\begin{array}{c}\text { Rendah } \\
(20 \%)\end{array}$ & $\begin{array}{c}40 \% \\
\text { ma mpu }\end{array}$ & $\begin{array}{c}70 \% \\
\text { mampu }\end{array}$ \\
\hline 3 & $\begin{array}{c}\text { Kemampuan menyusun } \\
\text { proposal KUR }\end{array}$ & 0 & $25 \%$ & $40 \%$ \\
\hline 4 & Peningkatan margin & $15 \%$ & $20 \%$ & $25 \%$ \\
\hline
\end{tabular}




\section{VI.PENUTUP}

Hasil dari pendampingan dan pelatihan kepada mitra usaha kecil menengah konveksi yang ada di desa Tri Tunggal Kecamatan Babat Lamongan dapat diketahui bahwa terdapat peningkatan kemampuan mitra dalam menggunakan teknologi produksi dan pemasaran sehingga mempunyai pengaruh terhadap peningkatan daya saing produk konveksi pada UD. Putra Tunggal. Hal ini dapat dilihat dari desain produk yang dihasilkan lebih variatif dan inovatif serta meningkatnya jumlah pelanggan. Untuk itu diperlukan peran pemerintah untuk lebih meningkatkan kemampuan usaha kecil menengah dibidang konveksi dalam penggunaan teknologi komputer sehingga produk yang dihasilkan lebih menarik serta dapat mengurangi biaya produksi sehingga mampu bersaing dengan kompetitor.Disamping itu pula kemampuan mitra dalam memasarkan produk juga mengalami peningkatan sejak digunakan e-commerce melalui pembuatan dan pengembangan website mitra jumlah pelanggan mengalami peningkatan dari 32 pelanggan meningkat menjadi 44 pelanggan selain itu harga jual produk juga mengalami peningkatan sebesar 7 persen hal ini dipengaruhi oleh banyaknya pembelian langsung dari produsen langsung kepada konsumen.Untuk itu diperlukan dukungan dari pemerintah dengan pemberian insentif untuk pengembangan e-commerce dengan mensosialisasikan kedalam jaringan kerja pemerintah khususnya dinas perdagangan dan UMKM.Dampak dari pelatihan dan pendampingan pengelolaan pembukuan dan keuangan usaha Mitra adalah peningkatan kemampuan pengelolaan keuangan yang dapat meningkatkan kedisiplinan dalam penggunaan keuangan sehingga keuntungan pengusaha kecil naik dari $15 \%$ menjadi 25\%.Selama ini Pemerintah Kabupaten Lamongan didalam memberikan program bantuan modal bergulir baik langsung maupun melalui perbankan masih sangat kurang. Hal ini sebenarnya sangat berasalan mengingat sebuah referensi[12] menyatakan bahwa; ciri dan problem UKM terdiri dari enam aspek. Pertama, kegiatannya cenderung tidak formal dan jarang yang memiliki rencana usaha. Kedua, struktur organisasinya bersifat sederhana. Ketiga, kebanyakan UKM tidak melakukan pemisahan antara kekayaan pribadi dengan kekayaan perusahaan. Keempat, sistem akuntansinya kurang baik, bahkan kadang-kadang tidak memilikinya sama sekali. Kelima, skala ekonominya kecil sehingga sulit untuk bisa menekan biaya. Keenam, kemampuan pemasaran dan diversifikasi pasarnya cenderung terbatas.Sehingga dengan pelatihan dan pendampingan produksi,pemasaran dan pengelolaan pembukuan dan keuangan pada usaha kecil menengah konveksi yang ada di desa Tri Tunggal Kecamatan Babat Lamongan akan dapat membantu menaikan daya saing mereka dan memudahkan pemerintah untuk melakukan sinergi dengan perbankan bagi pengembangan usaha kecil menengah sektor konveksi.

\section{REFERENSI}

[1]Adeosun, T.H., and Adetunde, I.A.,(2009) Strategic Application of Information and Communication Technology for Effective Service Delivery in Banking Industry. Journal of Social Science, 5(1), 47-51.

[2]Buhalis, D.(2003) eAirlines: Strategic and Tactical Use of ICTs in the Airlines Industry. Information and Management, 41, 805-825,

[3]Hengst, M., Sol, H.G. (2001) The Impact of Information and Communication Technology on Interorganizational Coordination: Guidelines from Theory. Informing Science, Special Series on Information Exchange in Electronic Markets.

[4]Apulu dan Latham (2011) Apulu, I., Latham, A. Driver for Information and Communication TechnologyAdoption: A Case Study of Nigerian Small and Medium Sized Enterprises. International Journal of Business and Management, Vol. 6, No. 5

[5]Alex ander, Y.Y. 2002. Enabling E-Commerce Growth Through The Social Construction Of A Virtual Community's Culture. Journal of Electronic Commerce Research,VOL. 3, NO. 4, 2002 Page 279

[6]Ramhmana, Arief (2009) Peranan Teknologi Informasi Dalam Peningkatan Daya Saing Usaha Kecil Menengah Prosiding Seminar Nasional Aplikasi Teknologi Informas i ( NA TI 2009) 1SSN: 1907-5022

[7]Hartini, Sri (2012) Peran Inovasi: Pengembangan Kualitas Produk dan Kinerja Bisnis, jurnal manajemen dan kewirausahaan, vol.14, no. 1

[8]Nonaka, lkujiro \& Tahachi, Hirotaka, (1995) " The Knowledge-reating Company: How Japanese Compainies Create the Dynamics of Innovation". Ox ford: Ox ford University Press,

[9]Setiarso, Bambang, (2005) Strategi Pengelolaan pengetahuan (Knowledge-Mangement) Untuk Meningkatkan Daya Saing Ukm, Proceeding. Seminar Nasional PESAT 2005 ISSN: 18582559

[10]Jauhari, Jaidan (2010). Upaya Pengembangan Usaha Kecil dan Menengah (UKM) dengan Memanfaatkan $e$ commerce, Jurnal Sistem Informasi (JSI), VOL. 2, NO. 1,

[11]Chambers, R.(1992)."Metode-metode Dalam Pengumpulan Informasi Sosial Untuk Proyek-proyek Pembangunan Pedesaan", dalam M.Cernea (eds), Mengutamakan Manusia dalam Pembangunan, Variabelvariabel Sosiologi di Dalam Pembangunan Pedesaan,Jakart a:UI Press.

[12] Mitzerg (Strat egi Managemen, New York, 1992) serta Musselman dan Hughes (Introduction to Modern Business, 1992) dikutip oleh Sutojo dkk, 1994, Profil Usaha Kecil dan Kebijakan Kredit Perbankan di Indonesia, Lembaga Manaj emen FE-UI, Jakarta. 